\title{
Differential assembly of $16 S$ rRNA domains during 30S subunit formation
}

\author{
ZHILI XU and GLORIA M. CULVER \\ Department of Biology, University of Rochester, Rochester, New York 14624, USA
}

\begin{abstract}
Rapid and accurate assembly of the ribosomal subunits, which are responsible for protein synthesis, is required to sustain cell growth. Our best understanding of the interaction of $30 \mathrm{~S}$ ribosomal subunit components (16S ribosomal RNA [rRNA] and 20 ribosomal proteins [r-proteins]) comes from in vitro work using Escherichia coli ribosomal components. However, detailed information regarding the essential elements involved in the assembly of $30 \mathrm{~S}$ subunits still remains elusive. Here, we defined a set of rRNA nucleotides that are critical for the assembly of the small ribosomal subunit in $E$. coli. Using an RNA modification interference approach, we identified 54 nucleotides in 16S rRNA whose modification prevents the formation of a functional small ribosomal subunit. The majority of these nucleotides are located in the head and interdomain junction of the $30 \mathrm{~S}$ subunit, suggesting that these regions are critical for small subunit assembly. In vivo analysis of specific identified sites, using engineered mutations in 16S rRNA, revealed defective protein synthesis capability, aberrant polysome profiles, and abnormal 16S rRNA processing, indicating the importance of these residues in vivo. These studies reveal that specific segments of 16S rRNA are more critical for small subunit assembly than others, and suggest a hierarchy of importance.
\end{abstract}

Keywords: ribosome assembly; modification interference; 16S rRNA; RNA-protein interactions

\section{INTRODUCTION}

The ribosome is an enormous ribonucleoprotein particle (RNP) composed of two-thirds RNA and one-third protein. The quick and accurate biogenesis of this large proteinsynthesizing machine is necessary for the viability and growth of all living cells (Warner et al. 2001). Bacterial ribosomes contain three RNAs (16S, 23S, and 5S ribosomal RNA [rRNA]) and more than 50 ribosomal proteins (r-proteins). The Escherichia coli ribosome has been extensively studied and has been a model for assembly studies as functional particles that can be reconstituted in vitro (Traub and Nomura 1968). The $E$. coli ribosomes can rapidly assemble in vivo in a matter of minutes (Schlessinger 1974; Lindahl 1975); by comparison, in vitro assembly features slow kinetics and a marked dependence on nonphysiological temperature and ionic conditions (Nomura and Traub 1968; Traub and Nomura 1968). This temperature dependence has been exploited to study ribosome assembly, with major thrusts focused on small subunit assembly (Sykes and Williamson 2009). At a low tem-

Reprint requests to: Gloria M. Culver, Department of Biology, University of Rochester, Rochester, NY 14624, USA; e-mail: gculver@ mail.rochester.edu; fax: (585) 275-2070.

Article published online ahead of print. Article and publication date are at http://www.rnajournal.org/cgi/doi/10.1261/rna.2246710. perature $\left(0^{\circ} \mathrm{C}-15^{\circ} \mathrm{C}\right)$, the $30 \mathrm{~S}$ subunit reconstitution stalls and a reconstitution intermediate $(\mathrm{RI})$ is formed (Fig. 1; Traub and Nomura 1969; Held and Nomura 1973). This intermediate can be converted to a functional $30 \mathrm{~S}$ particle upon incubation with additional r-proteins at an elevated temperature $\left(42^{\circ} \mathrm{C}\right)$. Intermediates with similar r-protein compositions have been observed in vivo, indicating the relevance of these intermediates to the 30 S subunit in vivo assembly (Guthrie et al. 1969; Lindahl 1975).

Previous studies of $30 \mathrm{~S}$ subunit assembly, including kinetic analyses (Talkington et al. 2005) and equilibrium titration experiments (Mizushima and Nomura 1970), have established an assembly sequence of the r-protein addition to $16 \mathrm{~S}$ rRNA (Fig. 1). Many experiments suggest that small subunit assembly can be considered to have an early stage, stage I, where early binding proteins (S4, S7, S8, S15, S17, and S20) and mid-binding proteins (S5, S6, S9, S11, S12, S13, S16, S18, and S19) bind to $16 \mathrm{~S}$ rRNA, and a late stage, stage II, where late-binding proteins (S2, S3, S10, S14, and S21) bind to $16 \mathrm{~S}$ rRNA. In both stages, the r-protein association is accompanied by significant conformational changes in $16 \mathrm{~S}$ rRNA both locally and globally during the formation of a functional 30S particle (Holmes and Culver 2004, 2005; Ramaswamy and Woodson 2009). Footprinting experiments have provided snapshots of $16 \mathrm{~S}$ rRNA conformations 


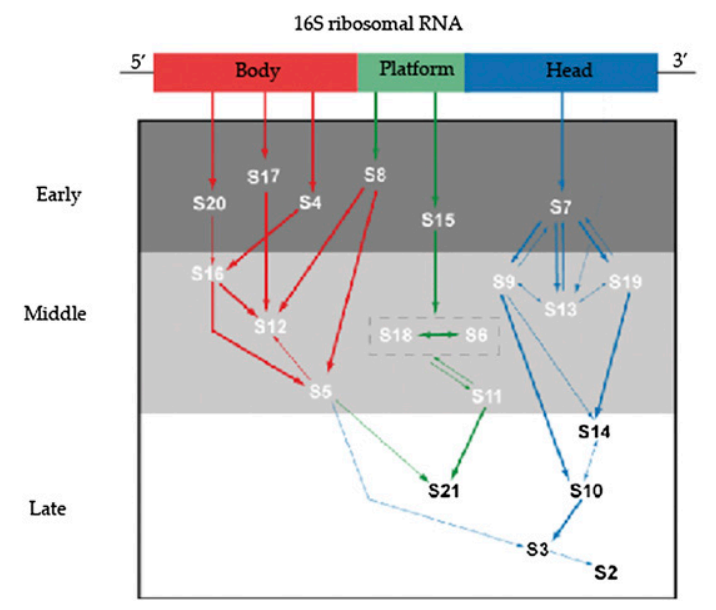

$16 \mathrm{~S}$ rRNA

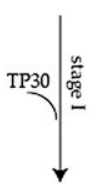

RI

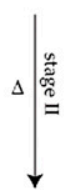

30 S subunits

FIGURE 1. Modified in vitro $30 \mathrm{~S}$ ribosomal subunit assembly map (Mizushima and Nomura 1970; Culver 2003; Grondek and Culver 2004). $16 \mathrm{~S}$ rRNA is shown in $5^{\prime}$ to $3^{\prime}$ direction. $16 \mathrm{~S}$ rRNA, composed of 5', central, and $3^{\prime}$ major domains forms the body, platform, and head of $30 \mathrm{~S}$ subunit, respectively. R-proteins are categorized into early, mid- and late-binding proteins. The arrows represent hierarchical binding of $r$-proteins. Red, green and blue arrows indicate the assembly of the body, platform and head of the small subunit, respectively. At stage I of assembly, early and mid-binding r-proteins bind to $16 \mathrm{~S}$ rRNA at low temperature to form RI. RI upon heating incorporates late-binding ribosomal proteins to form functional $30 \mathrm{~S}$ particles at stage II of assembly.

during the small subunit assembly process, and from these studies, the conformational changes of individual $16 \mathrm{~S}$ rRNA nucleotides have been revealed (Moazed et al. 1986; Stern et al. 1988). Nevertheless, the $16 \mathrm{~S}$ rRNA nucleotides that are critical to these rearrangements, and thus to the assembly of functional $30 \mathrm{~S}$ subunits, have yet to be defined. To address this problem, we have used a modification interference and selection scheme to identify the $16 \mathrm{~S}$ rRNA nucleotides critical for the $30 \mathrm{~S}$ subunits assembly in vitro (Fig. 2). We have identified 54 nucleotides (nt) that interfere with the $30 \mathrm{~S}$ subunit assembly. The majority of these nucleotides mapped to the $3^{\prime}$ domain and interdomain junction regions, indicating that assembly of these regions are less plastic than the assembly of other domains and that r-protein addition prior to modification does not greatly shift the modification patterns. Moreover, we engineered mutations in 16S rRNA at five individual sites identified in our in vitro selection and examined the mutants for variation in growth, ribosome biogenesis, and protein synthesis in vivo. The majority of plasmid encoded $16 \mathrm{~S}$ rRNA of mutants when expressed supported E. coli viability. However, when using a specialized ribosome system (Abdi and Fredrick 2005), most of these mutants had detrimental effects on protein synthesis. In addition, many of the mutants had aberrant polysome profiles and defects in 16S rRNA maturation, suggesting the importance of these residues in ribosome assembly.

\section{RESULTS}

\section{In vitro analysis}

\section{Experimental design and overview}

Modification interference has been used to identify nucleotides that are integral for RNP function and the interaction with appropriate ligands. For example, modification interference was used to identify nucleotides within the $30 \mathrm{~S}$ subunits important for subunit association (Pulk et al. 2006) and for tRNA binding (von Ahsen and Noller 1995). Our experimental design is an extension of this later procedure. To determine which nucleotides are important for the $30 \mathrm{~S}$ subunit assembly, nucleobase-specific chemical reagents, kethoxal (3-ethoxy- $\alpha$-ketobutyraldehyde) and DMS (dimethyl sulfate), were used to modify bases within the $16 \mathrm{~S}$ rRNA at two stages of the $30 \mathrm{~S}$ subunit reconstitution in vitro (Xu and Culver 2009). First, for investigating early stages (stage I) of small subunit assembly, naked 16S rRNA was modified prior to addition of r-proteins, and assembly was then allowed to proceed, otherwise unimpeded (Materials and Methods; Fig. 2A). Second, for investigating later stages (stage II) of small subunit assembly, $16 \mathrm{~S}$ rRNA and r-proteins were assembled at low temperature to form RI, and then this heterogeneous population of intermediates was modified (Materials and Methods; Fig. 2B) prior to a temperature shift to allow full assembly. Differences in tRNA binding capability were used to distinguish fully assembled, functional $30 \mathrm{~S}$ subunits from the stalled nonfunctional particles. Sites of

A

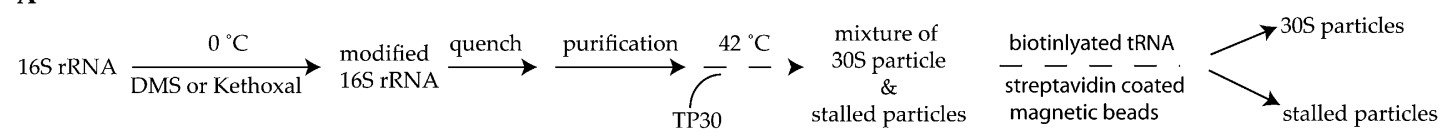

B

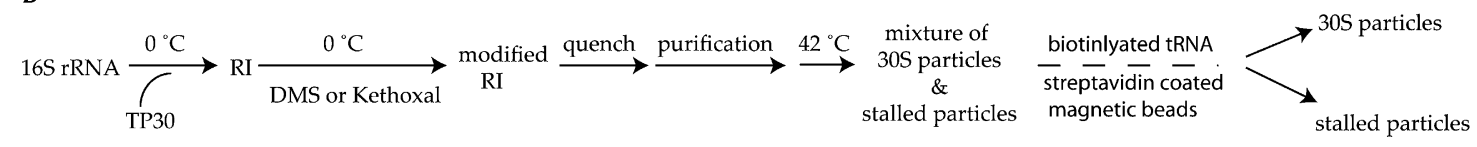

FIGURE 2. Experimental schemes for modification interference to identify critical nucleotides for stage I $(A)$ and stage II (B) of 30 S subunit assembly. 
modification in both the functional and stalled populations were then identified by primer extension analysis (Fig. 3). Comparison of $16 \mathrm{~S}$ rRNA modification patterns in the starting population with those of assembled/bound and the stalled/unbound particles revealed that $54 \mathrm{nt}$ had reduced reactivity in the functional population (Materials and Methods; Fig. 3), indicating that the 30 S subunit assembly is impaired by modification of these nucleotides.
Given that our means of partitioning the fully assembled 30S subunits from the stalled particles is the ability to bind tRNA, the identification of nucleotides critical for this function was expected. Both G926 and G1338 were identified as critical sites for tRNA binding to the $30 \mathrm{~S}$ subunits in a previous modification interference experiment (von Ahsen and Noller 1995). We also identified these residues, demonstrating that changes in our modification and selection
A

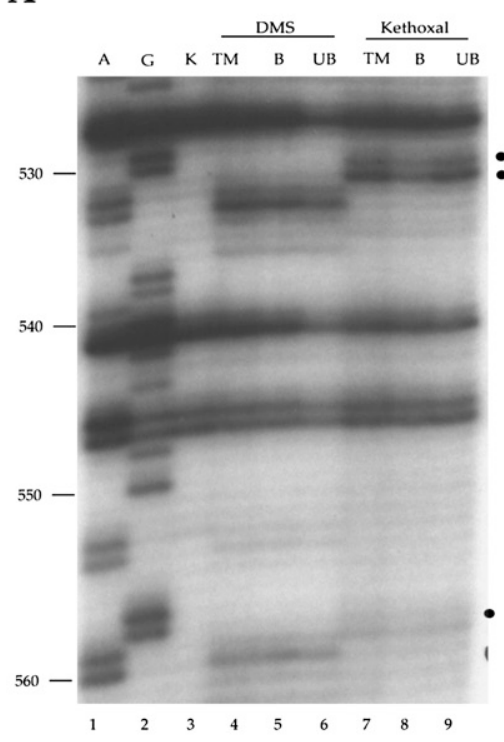

D

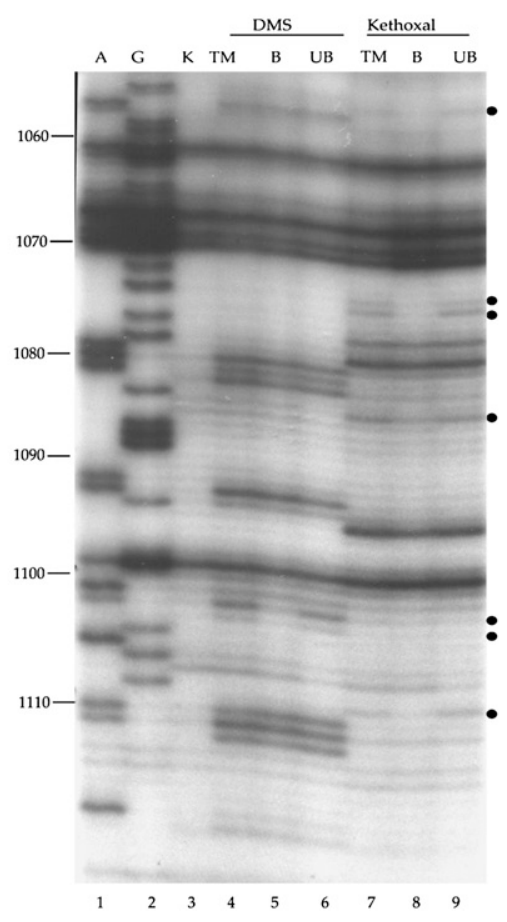

B

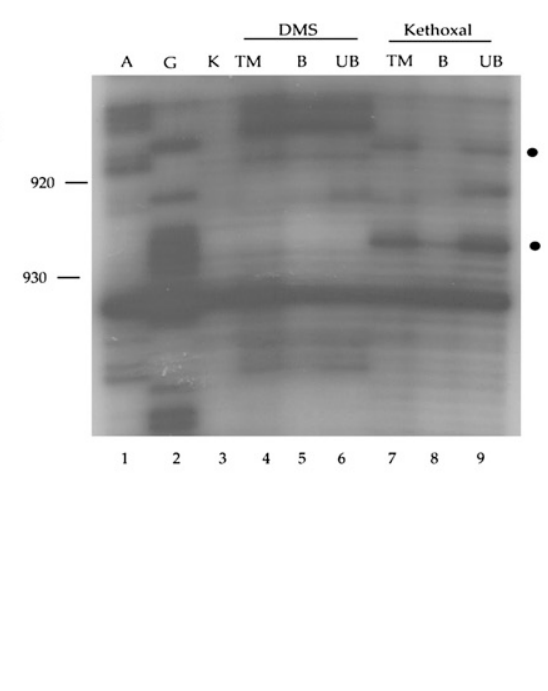

E

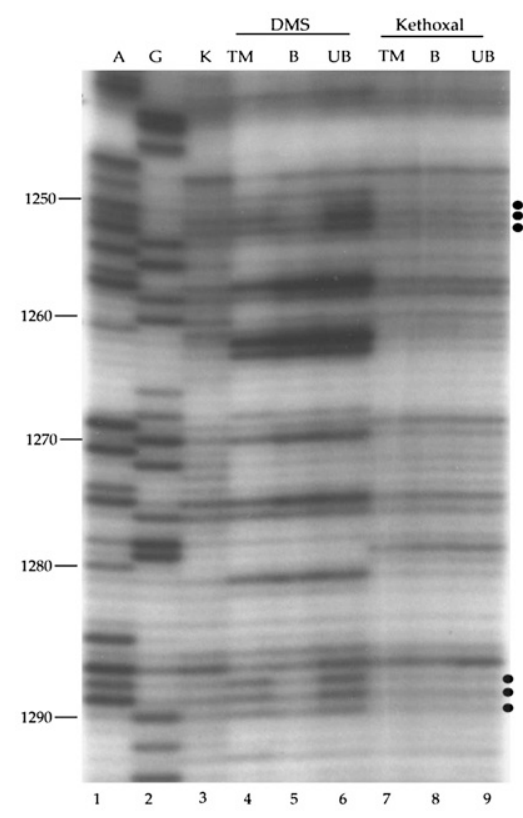

FIGURE 3. (Continued on next page)
C

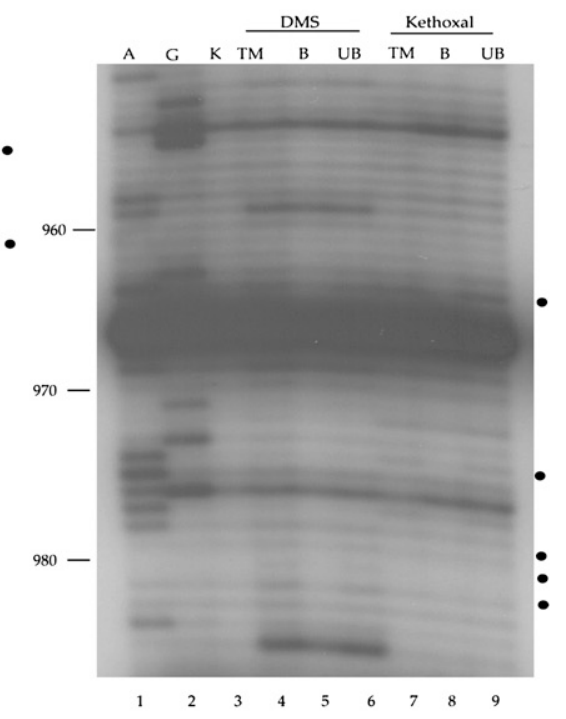

F

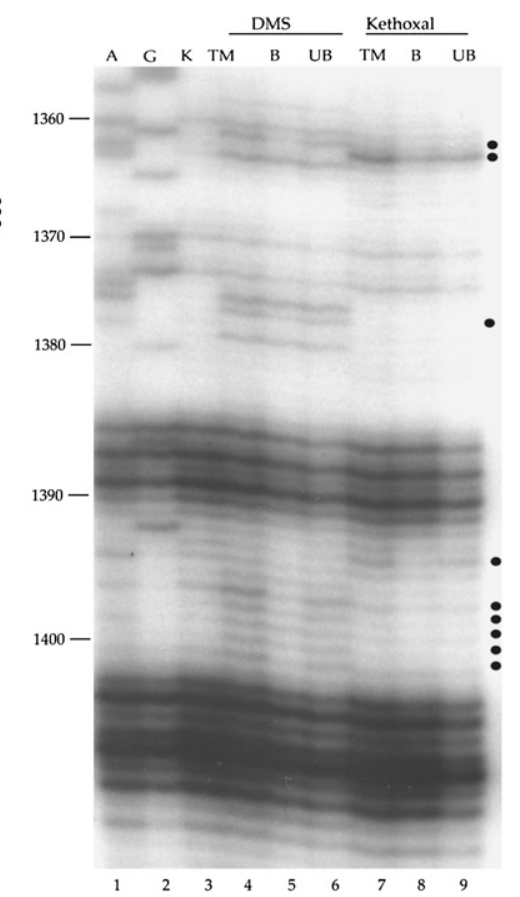


G

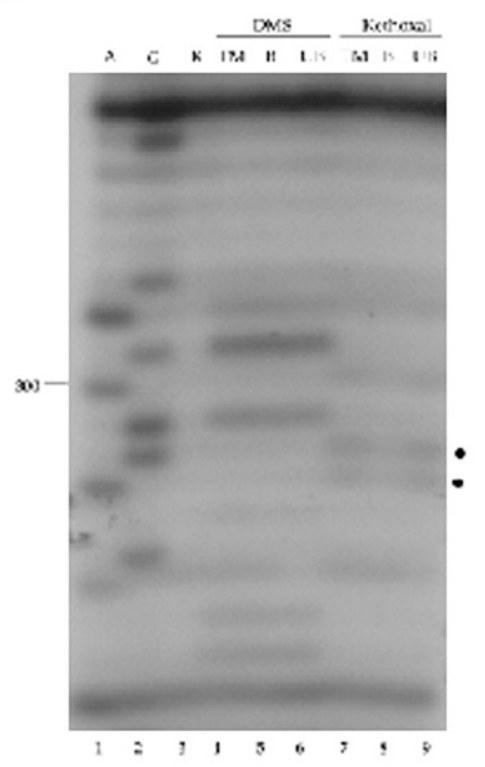

H

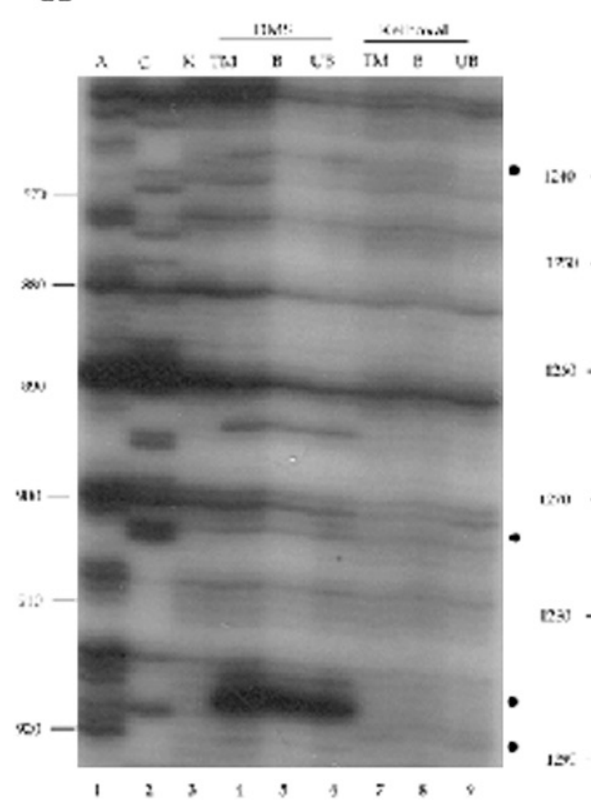

I

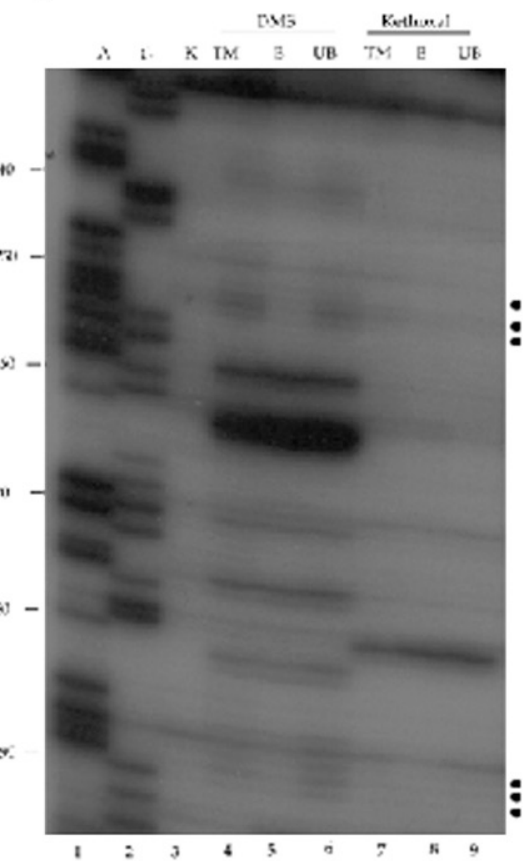

J

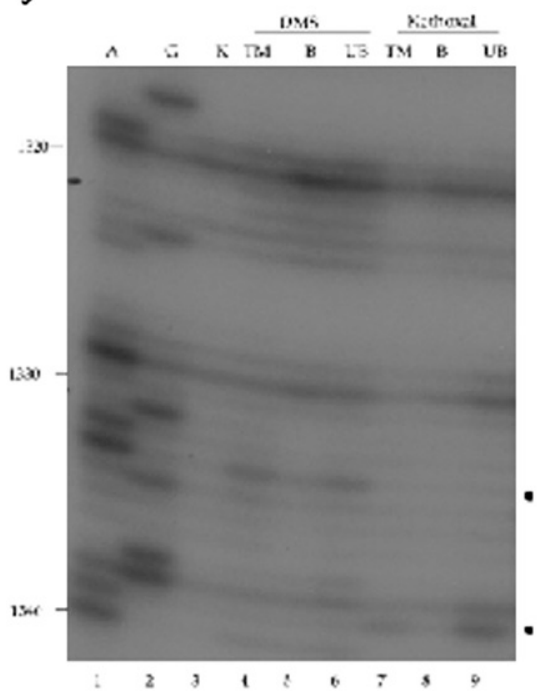

FIGURE 3. Primer extension analysis to identify DMS and kethoxal modified residues in $16 \mathrm{~S}$ rRNA. The lanes labeled $A$ and $G($ lanes 1,2$)$ are dideoxy sequencing lanes. The lane labeled $K$ (lane 3 ) is unmodified $16 \mathrm{~S}$ rRNA. The lanes marked with DMS and kethoxal denote samples were treated with those chemicals, respectively. TM (lanes 4,7) indicates total modified population of naked16S rRNA (stage I) or RI (stage II). B (lanes 5,8 ) indicates particles bound to tRNA, i.e., functional 30 S particles. UB (lanes 6,9 ) indicates particles unable to bind to tRNA, i.e., misassembled particles. Residues that have different reactivity in the TM, B, and UB lanes are marked with dots. ( $A-F)$ Stage I assembly; (G-J) stage II assembly. The primers used are as follows: $(A) 656,(B) 1046,(C) 1046,(D) 1190,(E) 1390,(F) 1508,(G) 323,(H) 1046,(I) 1390$, and $(J) 1508$.

protocol did not alter these findings. Nucleotides G529, G530, G926, G1338, and A1493 were all identified in our experiments and have been shown to change reactivity upon P-site tRNA binding (Moazed and Noller 1986, 1990), suggesting that these nucleotides may participate in the dynamic tRNA binding environment of the 30 S subunit. Thus, it is possible that the dynamic nature of this region may be important for $30 \mathrm{~S}$ subunit assembly and function. However, given our inability to distinguish effects due to loss of tRNA binding or assembly, these nucleotides were not examined in detail.

In general, modification of nucleotides in the body and platform of $30 \mathrm{~S}$ subunits appears to have minimal effects on assembly, with only 11 out of $915 \mathrm{nt}(1.2 \%)$ identified in these domains. In contrast, modification of 43 out of $627 \mathrm{nt}$ $(6.8 \%)$ in the $3^{\prime}$ domain alters assembly. These results are 
consistent with the polarity of assembly (Powers et al. 1993) and with the relatively high density of late-binding r-proteins that associate with the head of the small subunit (Powers et al. 1988; Wimberly et al. 2000; Schuwirth et al. 2005). Intriguingly, the majority of nucleotides whose modification impedes assembly are located not only in the head but also near the functional center of the $30 \mathrm{~S}$ subunit (Fig. 4), suggesting that interaction with $\mathrm{r}$-proteins and folding events in these regions may be particularly important for functional $30 \mathrm{~S}$ subunit formation.

Our data from the two modification schemes did not reveal clear delineations of regions critical at stage I or stage II. Generally, the data for the modification of naked $16 \mathrm{~S}$ rRNA or RI are interspersed. However, the findings that the $16 \mathrm{~S}$ rRNA domains have differences in sensitivity to modification interference are clear and indicate that changes in the 3 'domain are least tolerated.

\section{Nucleotides within the $5^{\prime}$ domain critical for $30 \mathrm{~S}$ subunit assembly}

The $5^{\prime}$ domain of $16 \mathrm{~S}$ rRNA (nucleotides 1-566) is the RNA component of the body of $30 \mathrm{~S}$ subunits that runs from the neck to the toe. Our data are consistent with earlier studies suggesting that the $5^{\prime}$ domain folds early during assembly and is mainly stabilized by RNA-RNA interactions (Stern et al. 1989; Adilakshmi et al. 2005). Five nucleotides (G301, G302, G529, G530, and G558) in the 5' domain were identified as critical for formation of functional 30S subunits (Fig. 4; Table 1). G529, whose modification could affect tRNA binding (Moazed and Noller 1990), was identified in both modification schemes. Modification of nucleotides G530 and G558 was refractory to stage I of assembly of the 30S subunit. Modification of nucleotides G301 and G302 shows an inhibitory effect to stage II assembly. Interestingly, all of identified nucleotides (G301, G302, and G529) whose modifications interfere with stage II assembly are indicated as interacting with S12 in the crystal structure of the E. coli small subunit (Fig. 4C; Schuwirth et al. 2005). These are the only modification sites in the body where r-protein/16S rRNA interactions appear to be disrupted. Also, S12 is poised on the functional face of the small subunit, and thus, an importance in assembly is expected.

\section{Nucleotides within the central domain critical for $30 \mathrm{~S}$ subunit assembly}

The central domain of 16S rRNA (nucleotides 567-915) with five associated $r$-proteins folds into the platform of the small subunit. Overall, there are $6 \mathrm{nt}$, which when modified, block assembly in the central domain (Fig. 4). G575, which is located in the single-stranded 570 loop, when modified in stage I, disrupts the assembly of small subunits. The crystal structure indicates that G575 interacts with C880 (Table 1; Schuwirth et al. 2005); thus, modification of this nucleotide could cause direct interruption of the base-pairing interface and result in stalled assembly. Modification of C737 and C738 in stage I of assembly impedes assembly, and these residues interact directly with S6 in the 30S subunit (Table 1; Schuwirth et al. 2005), supporting the known role of S6 in assembly (Traub and Nomura 1968). In addition, nucleotide A913, which interacts with S12 (Fig. 4C), when modified in stage II is refractory to small subunit formation. Moreover, modification of G791, located in the functionally important 790 loop (Lee et al. 1997), and G818, located in the singlestranded 820 loop, inhibits the formation of functional $30 \mathrm{~S}$ subunits. While these $2 \mathrm{nt}$ do not have direct identifiable interactions in the E. coli $30 \mathrm{~S}$ subunit crystal structure (Schuwirth et al. 2005), they could be involved in transient interactions during assembly of functional particles.

\section{Nucleotides within the $3^{\prime}$ major domain critical for $30 \mathrm{~S}$ subunit assembly}

The 3' major domain of 16S rRNA (nucleotides 916-1396) with associated r-proteins composes the head of the small subunit. The $3^{\prime}$ major domain features irregular packing interactions in contrast to the extensive helix stacking interaction in the 5' domain and the central domain (Wimberly et al. 2000; Schuwirth et al. 2005). In our collection of modified nucleotides that limit 30S subunit assembly, $30 \mathrm{nt}$ are part of the $3^{\prime}$ major domain (Table 1; Fig. 4). Overall, it appears that assembly of the head of the $30 \mathrm{~S}$ subunit is most susceptible to nucleotide modification interference.

Twenty nucleotides in the $3^{\prime}$ major domain identified as important for assembly interact directly with r-proteins. Most of these residues map to mid-late-binding r-proteins in the 3' major domain (Table 1). The only exceptions are nucleotides A1289 and A1375, which interact with the early binding r-protein S7. Many other residues (G963, C979, A983, G1074, A1101, A1102, G1108, G1316, and C1359) have direct interaction with S2, S3, S10, and S14 (Table 1; Schuwirth et al. 2005), and modifications of these residues can be linked to stalled assembly. Thus, accommodation of these proteins in the formation of the head of the $30 \mathrm{~S}$ subunit is likely to be a critical stage of assembly.

In addition to the r-protein/16S rRNA interaction, the 14 nt identified in the $3^{\prime}$ major domain are implicated in specific base pairs (Table 1; Schuwirth et al. 2005). Modification of such nucleotides could cause direct disruption of the basepairing interface and thus result in stalled assembly. For example, modification of residues A1288 and C1249 restricts closing an internal loop in helix 41 (Fig. 4D); modifications that could block a base triple interaction between G1053, G1057, and C1203 are also refractory to assembly (Fig. 4E).

\section{Nucleotides within the $3^{\prime}$ minor domain critical for $30 \mathrm{~S}$ subunit assembly}

The $3^{\prime}$ minor domain (nucleotide 1397-1542) comprises the penultimate and ultimate stem of $16 \mathrm{~S}$ rRNA, which spans 


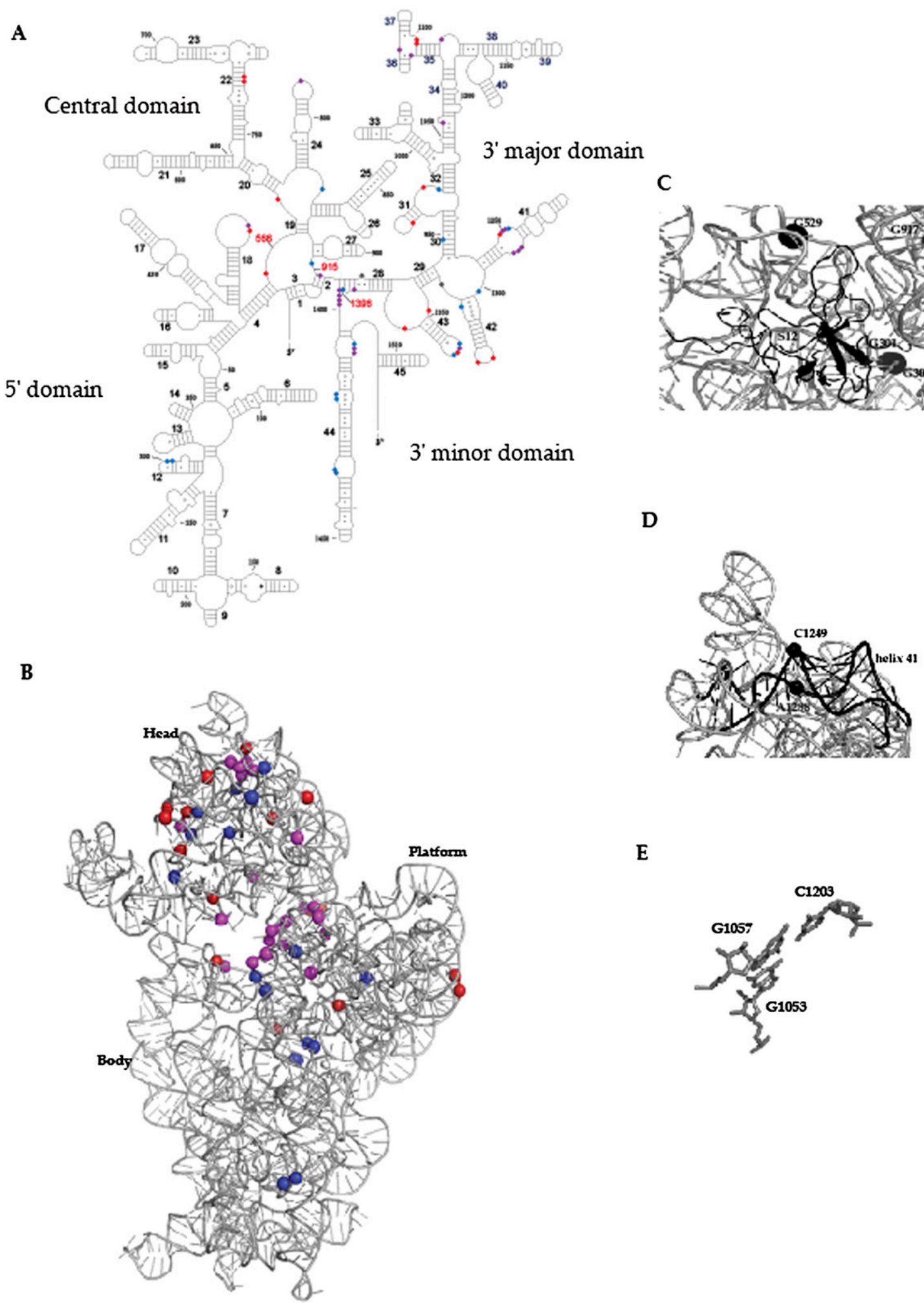

FIGURE 4. Nucleotides identified as critical for the small subunit assembly shown on secondary (Cannone et al. 2002) and tertiary (Protein Data Bank [PDB] 2AW7) (Schuwirth et al. 2005) structure of $16 \mathrm{~S}$ rRNA in $30 \mathrm{~S}$ subunit. $(A)$ The $5^{\prime}$, central, $3^{\prime}$ major, and $3^{\prime}$ minor domain boundaries are indicated in red and are defined in the text. Red circles denote to residues refractory to small subunit assembly when modified at stage I, blue circles denote to residues refractory to small subunit assembly when modified at stage II, purple circles denote those residues whose modification are refractory to both stages of assembly, and gray circles denote to residues critical to tRNA binding (von Ahsen and Noller 1995). (B) 16S rRNA from $30 S$ subunit is shown in gray. Nucleotides that are critical for early stage of the small subunit assembly are shown in red spheres. Nucleotides that are critical for late stage of the small subunit assembly are shown in blue spheres. Nucleotides that are critical for both stages of the small subunit assembly are shown in purple spheres. $(C)$ Nucleotides refractory to the small subunit assembly interacting with S12 are marked. S12 is shown in dark cartoon form. (D) Base interactions identified as important in helix 41, which is colored in dark. (E) Base triple interactions between G1053, G1057, and C1203, which appear to be important for assembly. All the figures are generated using PyMOL and PDB 2AW7 (Schuwirth et al. 2005). 
TABLE 1. Nucleotides critical for $30 \mathrm{~S}$ subunit assembly as identified by modification interference

\begin{tabular}{|c|c|c|c|}
\hline Nucleotide & Assembly stage & Effector & $\begin{array}{c}\text { Observed rates of RNA } \\
\text { backbone protection }\left(\mathrm{sec}^{-1}\right)^{\mathrm{a}}\end{array}$ \\
\hline 301G & Stage II & 296 U/S12/S17 & $\leq 0.02$ \\
\hline $302 \mathrm{G}$ & Stage II & 295C/S12/S13 & $\mathrm{N} / \mathrm{A}$ \\
\hline 529G & Both & S12 & 0.73 \\
\hline 530G & Stage I & & Prot \\
\hline 558G & Stage I & $26 \mathrm{~A}$ & $\mathrm{~N} / \mathrm{A}$ \\
\hline $575 G$ & Stage I & 880 C & $\geq 20$ \\
\hline $737 C$ & Stage I & $669 \mathrm{G} / \mathrm{S} 5 / \mathrm{S} 6$ & 13 \\
\hline $738 \mathrm{C}$ & Stage I & $668 \mathrm{G} / \mathrm{S} 5 / \mathrm{S} 6$ & N/A \\
\hline 791G & Both & & N/A \\
\hline 818G & Stage II & & $\mathrm{N} / \mathrm{A}$ \\
\hline $913 \mathrm{~A}$ & Stage II & $\mathrm{S} 12$ & 19 \\
\hline 917G & Both & $18 \mathrm{C}$ & $\leq 0.02$ \\
\hline 926G & Both & & $\mathrm{N} / \mathrm{A}$ \\
\hline 949A & Stage II & 1232 U/S13 & $\leq 0.02$ \\
\hline 963G & Stage I & 972 C/S10 & N/A \\
\hline $979 C$ & Stage I & S14 & $\geq 20$ \\
\hline $983 \mathrm{~A}$ & Stage II & S14 & 16 \\
\hline 1053G & Both & 1057 G & $\leq 0.02$ \\
\hline 1074G & Both & 1083 U/S2 & $\leq 0.02$ \\
\hline 1084G & Both & & $\leq 0.02$ \\
\hline $1101 \mathrm{~A}$ & Stage I & S2 & N/A \\
\hline $1102 \mathrm{~A}$ & Stage I & 1073 U/S2 & $\mathrm{N} / \mathrm{A}$ \\
\hline 1108G & Both & S3 & $\leq 0.02$ \\
\hline $1249 C$ & Stage I & $1288 \mathrm{~A} / \mathrm{S} 9$ & $\geq 20$ \\
\hline $1250 \mathrm{~A}$ & Both & S9 & $\geq 20$ \\
\hline $1251 \mathrm{~A}$ & Both & S9 & $\geq 20$ \\
\hline $1252 \mathrm{~A}$ & Stage II & $1285 \mathrm{~A}$ & $\mathrm{~N} / \mathrm{A}$ \\
\hline $1287 \mathrm{~A}$ & Both & & $\mathrm{N} / \mathrm{A}$ \\
\hline $1288 \mathrm{~A}$ & Both & 1249 C & N/A \\
\hline $1289 \mathrm{~A}$ & Both & S7/S9 & $\leq 0.02$ \\
\hline $1302 C$ & Stage II & S13 & N/A \\
\hline 1316G & Stage I & S14/S19 & N/A \\
\hline $1319 A$ & Stage I & 1315 U/S19 & $\leq 0.02$ \\
\hline $1332 \mathrm{~A}$ & Stage II & S13 & $\mathrm{N} / \mathrm{A}$ \\
\hline 1338G & Both & & N/A \\
\hline $1349 A$ & Stage I & $1273 \mathrm{G} / \mathrm{S} 9$ & $\leq 0.02$ \\
\hline $1359 \mathrm{C}$ & Stage II & S14 & N/A \\
\hline $1360 \mathrm{~A}$ & Both & 978 A/S14 & N/A \\
\hline $1361 G$ & Stage I & & $\mathrm{N} / \mathrm{A}$ \\
\hline $1362 \mathrm{~A}$ & Stage II & $1224 \mathrm{U}$ & 7 \\
\hline $1375 \mathrm{~A}$ & Stage I & 1346 A/S7 & $\leq 0.02$ \\
\hline 1392G & Both & 924 C & N/A \\
\hline 1395C & Stage II & $922 \mathrm{G}$ & $\leq 0.02$ \\
\hline 1396A & Both & $921 \mathrm{U}$ & $\leq 0.02$ \\
\hline 1397C & Both & & $\mathrm{N} / \mathrm{A}$ \\
\hline 1398A & Both & & $\leq 0.02$ \\
\hline $1399 C$ & Both & $1504 \mathrm{G}$ & $\leq 0.02$ \\
\hline 1416G & Stage II & $1484 \mathrm{C}$ & $\mathrm{N} / \mathrm{A}$ \\
\hline 1417G & Stage II & & $\leq 0.02$ \\
\hline $1433 \mathrm{~A}$ & Stage II & & $\leq 0.02$ \\
\hline $1434 \mathrm{~A}$ & Stage II & & $\leq 0.02$ \\
\hline $1492 \mathrm{~A}$ & Stage II & & N/A \\
\hline $1493 \mathrm{~A}$ & Both & & $\mathrm{N} / \mathrm{A}$ \\
\hline 1494G & Both & $1407 \mathrm{C}$ & $\mathrm{N} / \mathrm{A}$ \\
\hline
\end{tabular}

Interactions between identified nucleotides and other elements of $30 \mathrm{~S}$ subunit are extracted from crystal structure of $E$. coli small subunits (2AW7) using Entangle (Allers and Shamoo 2001).

${ }^{a}$ Rates of RNA backbone protection from hydroxyl radical cleavage (Adilakshmi et al. 2008) are given. N/A indicates data for these nucleotides are not available. from the body to the head of the small subunit. In the $3^{\prime}$ minor domain, the modification of $13 \mathrm{nt}$ disrupts the assembly of 30 S subunit (Table 1; Fig. 4). These residues are critical for stage II or at both stages of assembly. Although, we cannot pinpoint any RNA/r-protein interaction with these residues, 6 nt (G1392, C1395, A1396, C1399, G1416, and G1494) are implicated in a specific base-pairing interaction in the crystal structure of the E. coli small subunits (Schuwirth et al. 2005). The percentage of residues refractory to assembly in the $3^{\prime}$ minor domain (9\%) suggests that limiting the extension or stabilization of helix 44 may be detrimental to assembly. In addition, residues G1392, C1395, and A1396 in helix 28, which are predicted to be in base pairs in the secondary structure (Cannone et al. 2002), are susceptible to modification, and such modifications limit assembly. These data suggest that formation of both helix 26 and helix 44 is a critical event in functional $30 \mathrm{~S}$ subunit formation. Overall, the data presented herein indicate that the individual domains of 16S rRNA have different sensitivity to nucleotide modification in vitro.

\section{In vivo studies}

To further verify the importance of identified nucleotides in the small subunit ribosome assembly, we constructed mutations at several selected residues in $16 \mathrm{~S}$ rRNA for in vivo analysis. Thus, examination of the effect caused by the mutation of these residues in vivo may produce insight into a broad range of assembly defects. Given that our in vitro data pointed to the importance of the $3^{\prime}$ domain in assembly, we focused on these residues for in vivo analysis. Three approaches to study the effect of mutations at five residues $(917,1053,1084$, 1101 , and 1108 ) in vivo were undertaken. First, the overall impact of mutation was examined by assessing translation competency. Second, the ribosome profiles from strains bearing mutations were examined. Lastly, the 16S rRNA maturation was examined.

We used a specialized ribosome system to monitor translation capability. 
This system uses a plasmid encoded 16S rRNA gene with an altered anti-Shine-Dalgarno sequence (GGGGU), and an E. coli strain KLF10, with a chromosomal copy of the $\beta$-galactosidase gene (lacZ) with an altered Shine-Dalgarno sequence (the ribosome binding site, AUCCC) (Abdi and Fredrick 2005). Thus, the $30 \mathrm{~S}$ subunits assembled from the plasmid-encoded $16 \mathrm{~S}$ rRNA translate only the lacZ mRNA, while the wild-type cellular ribosomes translate the wild-type cellular mRNAs. The level of $\beta$-galactosidase activity mirrors the quality of the $30 \mathrm{~S}$ subunits composed of plasmid-derived borne $16 \mathrm{~S}$ rRNA. The $\beta$-galactosidase activity assay revealed that various mutations at position G1084 reduced the protein synthesis capabilities to less than $40 \%$ of that for ribosomes with control $16 \mathrm{~S}$ rRNA (Fig. 5). By comparison, mutations at position G917, G1053, A1101, and G1108 resulted in nearly undetectable levels of translation (Fig. 5). These results suggest the importance of the specific identity of nucleotides for protein synthesis and possibly for assembly.

To examine if these mutations directly alter ribosome biogenesis, we analyzed polysome profiles using a system that allows the regulated expression of plasmid-derived $16 \mathrm{~S}$ rRNA with mutations at positions G917, G1053, A1101, and G1108. Upon induction, plasmid encoded 16S rRNA accounts for around $60 \%$ of total cellular $16 \mathrm{~S}$ rRNA in wild-type strains (Table 2; Powers and Noller 1991; Yassin et al. 2005). In contrast, the percentage of plasmid encoded 16S rRNA in mutant strains varies (see Discussion; Table 2). For each

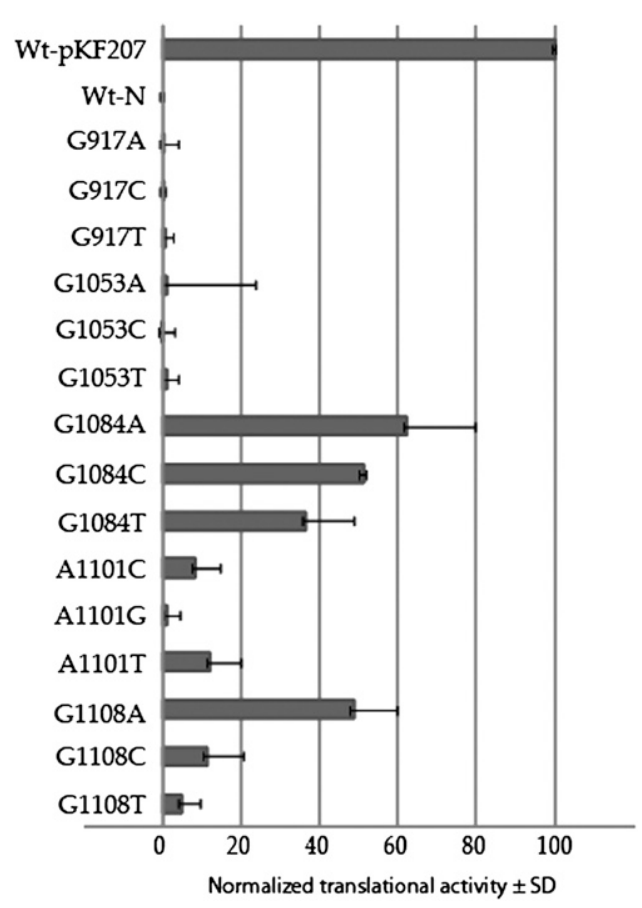

FIGURE 5. Effect of mutations at indicated positions in $16 \mathrm{~S}$ rRNA on translation activity as monitored by $\beta$-galactosidase activity using a specialized ribosome system (Abdi and Fredrick 2005). All values are normalized to $16 \mathrm{~S}$ rRNA with anti-SD mutations but otherwise wildtype sequence. tested mutation, the polysome profiles were altered compared to plasmid-derived wild-type $16 \mathrm{~S}$ rRNA. A reduction in the $70 \mathrm{~S}$ peak area with concurrent increase in free subunits was observed, with variations ranging from a slight increase in free 30 S subunits of 1.6 -fold (1084 and 1108) to nearly 3.5-fold (1053 and 1101). Moreover, strains containing the 16 S rRNA mutations G1053A, G1053C, or A1101C not only exhibited diminished $70 \mathrm{~S}$ particles relative to free $30 \mathrm{~S}$ subunits but also aberrant 30 S subunit peaks (Fig. 6). Thus, these mutations clearly have an impact on the $30 \mathrm{~S}$ subunit assembly in vivo. These results pinpoint the importance of these specific residues in this process. Additionally, we wished to address whether the accumulated ribosomal particles were fully mature. Analysis of the rRNA from $30 \mathrm{~S}$ subunit and $70 \mathrm{~S}$ ribosome fractions from strains carrying specific mutants (G1053A, G1053C, G1084T, A1101C, A1101G, and G1108T) revealed that $16 \mathrm{~S}$ rRNA processing was abnormal compared with wild type. The percentage of pre-16S rRNA (17S rRNA) in the ribosomal $30 \mathrm{~S}$ and $70 \mathrm{~S}$ fractions from the mutant strains increased, indicating defective $16 \mathrm{~S}$ rRNA maturation (Table 2). While these changes are modest, when the relative proportions of chromosomally encoded (wild type) versus plasmid-borne (mutant) $16 \mathrm{~S}$ rRNA is considered, these differences are more significant. These results corroborate our in vitro data and indicate that these residues are critical for accurate and appropriate $30 \mathrm{~S}$ subunit biogenesis in vivo.

\section{DISCUSSION}

We have identified nucleotides that are critical for $30 \mathrm{~S}$ subunit assembly by using modification interference and in vivo analysis. These data are consistent with the polar nature of the assembly of the 30S subunit (Powers et al. 1993; Holmes and Culver 2005). It appears that the assembly of the $5^{\prime}$ domain and central domain is mostly resistant to modification interference, and this is not due to differences in the number of modified residues observed in the total pool for these domains (data not shown). Conversely, modifications within the $3^{\prime}$ major and minor domains as well as at the tertiary interaction sites appear to be refractory for assembly. Moreover, in vivo studies support the importance of these residues for small subunit assembly and functional $70 \mathrm{~S}$ ribosome formation. Overall, these data might suggest that specific modification within the $5^{\prime}$ and central domains can be overcome during the assembly process, while this is not the case for the $3^{\prime}$ major and minor domains.

Our data indicate that the binding of many early and midassociating r-proteins cannot be disrupted by modification interference. It is possible, as suggested for the $5^{\prime}$ domain, that much of the functional architecture can be formed within naked 16S rRNA and that protein association is secondary (Stern et al. 1988). Alternatively, it is possible that there are redundant, alternative pathways for assembly of the $5^{\prime}$ and central domains such that specific rearrangements 
TABLE 2. The percentage of precursor $16 \mathrm{~S}$ rRNA and plasmid-borne $16 \mathrm{~S}$ rRNA as detected by primer extension

\begin{tabular}{|c|c|c|c|c|}
\hline \multirow[b]{2}{*}{ Mutant position } & \multicolumn{2}{|c|}{ Percentage of pre-16S rRNA } & \multicolumn{2}{|c|}{ Percentage plasmid-borne $16 \mathrm{~S}$ rRNA } \\
\hline & Free $30 S$ subunits & $70 S$ ribosomes & Free $30 S$ subunits & $70 \mathrm{~S}$ ribosomes \\
\hline Wild type & $15 \pm 2 \%$ & $0.74 \pm 0.04 \%$ & $64 \pm 2.4 \%$ & $62 \pm 2.0 \%$ \\
\hline G917C & $55 \pm 6.3 \%$ & $1.24 \pm 0.44 \%$ & $54 \pm 5.9 \%$ & $3 \pm 1.6 \%$ \\
\hline G917T & $62 \pm 10.3 \%$ & $1.26 \pm 0.06 \%$ & $49 \pm 1.3 \%$ & $10 \pm 1.3 \%$ \\
\hline G1053A & $38 \pm 5.6 \%$ & $2.76 \pm 0.18 \%$ & $73 \pm 1.8 \%$ & $58 \pm 2.1 \%$ \\
\hline G1053C & $41 \pm 3.8 \%$ & $4.57 \pm 0.34 \%$ & $69 \pm 1.1 \%$ & $31 \pm 6.2 \%$ \\
\hline G1084A & $29 \pm 5.5 \%$ & $2.42 \pm 0.09 \%$ & $76 \pm 1.3 \%$ & $67 \pm 0.8 \%$ \\
\hline G1084C & $29 \pm 3.9 \%$ & $2.01 \pm 0.20 \%$ & $79 \pm 1.8 \%$ & $65 \pm 3.6 \%$ \\
\hline G1084T & $27 \pm 2.6 \%$ & $1.93 \pm 0.16 \%$ & $71 \pm 0.3 \%$ & $53 \pm 2.2 \%$ \\
\hline A1101C & $51 \pm 11.3 \%$ & $4.42 \pm 0.77 \%$ & $53 \pm 3.2 \%$ & $15 \pm 0.2 \%$ \\
\hline A1101G & $22 \pm 3.3 \%$ & $1.36 \pm 0.05 \%$ & $57 \pm 3.3 \%$ & $38 \pm 3.1 \%$ \\
\hline G1108A & $25 \pm 0.4 \%$ & $1.57 \pm 0.45 \%$ & $58 \pm 0.4 \%$ & $76 \pm 0.2 \%$ \\
\hline G1108C & $32 \pm 0.8 \%$ & $1.16 \pm 0.31 \%$ & $61 \pm 3.1 \%$ & $70 \pm 0.3 \%$ \\
\hline G1108T & $36 \pm 0.9 \%$ & $3.19 \pm 1.01 \%$ & $70 \pm 5.3 \%$ & $72 \pm 4.8 \%$ \\
\hline
\end{tabular}

can be circumvented. However, the assembly of the $3^{\prime}$ domain appears to be more restricted. In previous work, pulsechase quantitative mass spectrometry of kinetics accessing r-protein association (Talkington et al. 2005) and timeresolved hydroxyl radical probing of $16 \mathrm{~S}$ rRNA nucleotides during 30 S subunit assembly (Adilakshmi et al. 2008) have suggested that assembly of the $3^{\prime}$ domain is slow relative to the other domains. Thus, assembly kinetics may reflect differences in parallel pathways that allow functional 30S subunits to be formed. Consistent with this hypothesis, three of the $6 \mathrm{nt}$ in the $5^{\prime}$ domain identified in this work interact with $\mathrm{S} 12$, which is one of the slowest binding r-proteins (Talkington et al. 2005). Thus, the flexibility of assembly of the $5^{\prime}$ and central domains when nucleotides are modified may be linked to redundant folding pathways and could further explain the fast assembly/folding kinetics observed in these other experiments (Talkington et al. 2005; Adilakshmi et al. 2008). The susceptibility of the $3^{\prime}$ domain to modification, which restricts assembly, is significantly more pronounced, and in light of the slower kinetics for assembly of this domain (Talkington et al. 2005; Adilakshmi et al. 2008), it is plausible that there is a more restricted assembly landscape for the head of the 30 S subunit.

Alternative explanations for the differences between the domains are also possible. The 3' domain may be more susceptible to folding traps and require the action of extra ribosomal factors for proper formation. This might suggest that many alternative conformations of the $3^{\prime}$ domain are not available. Examination of RNA backbone protection rates (available for only a subset of the nucleotides identified herein) (Adilakshmi et al. 2008) suggests that critical residues belong to either the very fast or slow kinetic groupings (see Table 1). These correlations may suggest that the intermediate

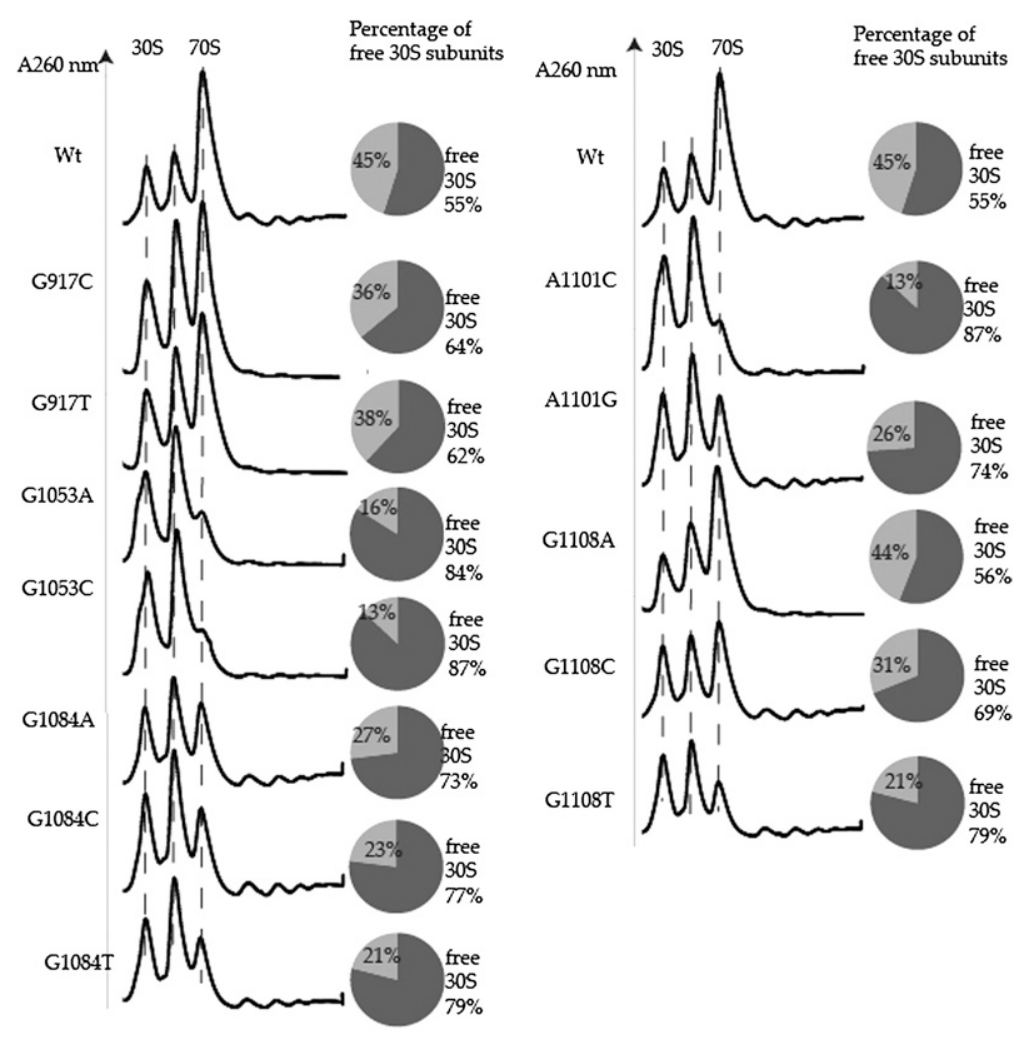

FIGURE 6. Effects of mutations at indicated positions in $16 \mathrm{~S}$ rRNA on polysome profiles. The scale of all profiles is the same. The percentage of free $30 \mathrm{~S}$ subunits (dark gray) relative to $30 \mathrm{~S}$ subunits in $70 \mathrm{~S}$ ribosomes (light gray) is given. 
landscape is more plastic and that early (fast) or late (slow) events are more critical to the process.

Our in vivo results strongly support our in vitro selection data. The results from translation read-out, polysome profiles, and precursor $16 \mathrm{~S}$ rRNA analysis reflect the importance of these nucleotides in the small subunit assembly in vivo. However, there are subtleties revealed by the mutational analysis data. Defects of most analyzed mutants (G917C, G917T, G1053A, G1053C, A1101C, and G1108T) appeared to be most likely caused by ribosome biogenesis defects (Figs. 5 and 6; Table 2). Conversely, mutations at residues 1084 and 1108 (except G1108T) probably impair function of the ribosome (Figs. 5 and 6; Table 2).

Previous studies have shown that mutation of the residue G917 significantly perturbs the translational activity of ribosomes (Brink et al. 1993). This is consistent with our results using the specialized ribosome system (Fig. 5). Our analysis of mutations at position 917 reveal that there is still a significant $70 \mathrm{~S}$ population (Fig. 6); however, these $70 \mathrm{~S}$ ribosomes contain very little mutant $16 \mathrm{~S}$ rRNA (see Table 2). Thus, this lack of function could result from a problem in completing $30 \mathrm{~S}$ subunit biogenesis, as suggested by the increase in precursor $16 \mathrm{~S}$ rRNA in both free and associated subunits in these strains (Table 2) and possibly defects in translation initiation.

Mutations at residue 1053 resulted in no translational activity using the specialized ribosome system (Fig. 5) in addition to increased precursor $16 \mathrm{~S}$ rRNA in 70S ribosome (approximately sixfold compared with wild type in G1053C strain) (Table 2). Changes in the percentage of mutant $16 \mathrm{~S}$ rRNA presented in the 70S ribosome compared with wild type are relatively mild. Thus, the lack of function of these mutant strains could be caused by pre-rRNA processing and/ or assembly defects. This mutation may disrupt the triple base interaction between G1053, G1057, and C1203 (Fig. 4E). This indicates architectural changes during assembly are complex and multifaceted.

Variant mutations at the same position (residues 1108 and 1084) appear to have different effects. Mutation from guanine to adenine at residue 1108 decreased the translation activity to around $50 \%$ of wild type (Fig. 5). In contrast, mutation from guanine 1108 to cytosine or uracil decreased the translation activity to less than $10 \%$ of wild type (Fig. 5). Accordingly, polysome profiles of G1108A are similar to the wild-type profiles, while G1108C is slightly different (Fig. 6). In addition, changes in $16 \mathrm{~S}$ rRNA processing in the G1108A mutant strain are rather subtle (Table 2). Thus, it appears that a purine at this position is better tolerated and may be important for interaction with S3 (Schuwirth et al. 2005). Change of precursor 16S rRNA in these strains (except G1108T) is modest compared with wild type in both $30 \mathrm{~S}$ subunits and $70 \mathrm{~S}$ ribosomes. Therefore, mutations at these positions are most likely defective in ribosome function. However, we cannot eliminate the possibility of these mutations being disruptive to ribosome assembly.
Our data suggest that individual domains of 16S rRNA have distinct assembly properties. Assembly of the $5^{\prime}$ and central domains appears to be more plastic, while assembly of the $3^{\prime}$ major and minor domains is more complex. These differences could explain the high density of late-binding r-proteins (four of five) that interact with the $3^{\prime}$ major domain. These r-proteins and perhaps biogenesis factors as well, may act to direct assembly and appropriate folding of the $3^{\prime}$ major domain.

\section{MATERIALS AND METHODS}

\section{Biotinylation of tRNA}

Biotinylation of tRNA was performed as described (von Ahsen and Noller 1995) with the following modification: $100 \mathrm{nmol}$ of S. cerevisiae $\mathrm{tRNA}^{\text {phe }}$ was incubated with $10 \mathrm{mM}$ potassium periodate in $4 \mathrm{~mL}$ of $100 \mathrm{mM}$ sodium acetate solution ( $\mathrm{pH} 5.5$ ) for $30 \mathrm{~min}$ on ice in the dark. Extra sodium periodate was removed by washing the oxidized tRNA with $100 \mathrm{mM}$ sodium acetate solution ( $\mathrm{pH}$ 5.5) on a Centricon-10 at $6000 \mathrm{rpm}$ for $2 \mathrm{~h}$ at $4^{\circ} \mathrm{C}$ to a volume of $1 \mathrm{~mL}$. The above-treated oxidized tRNA was then incubated with $100 \mu \mathrm{L}$ of $50 \mathrm{mM}$ biotin hydrazide (in DMSO) for $2 \mathrm{~h}$ at room temperature in the dark. Additional biotin hydrazide was removed on a Microcon-10 column at 8000 rpm, and biotinlyated tRNA was stabilized by adding an equal volume of $0.2 \mathrm{M}$ sodium borahydride and a twofold volume of $1 \mathrm{M}$ Tris- $\mathrm{Cl}$ ( $\mathrm{pH}$ 8.2) with incubation on ice for $30 \mathrm{~min}$ in the dark. After ethanol precipitation, the biotinylated tRNA was redissolved in $200 \mu \mathrm{L} 100 \mathrm{mM}$ sodium acetate ( $\mathrm{pH}$ 5.5). Excess salt was removed by dialyzing the biotinylated tRNA in $100 \mathrm{mM}$ sodium acetate. The concentration of the biotinylated tRNA was determined by absorbance at $\mathrm{A}_{260}$ and Pierce biotin quantitation kit.

\section{Modification interference}

Chemical probing conditions were determined empirically by titrating the modification reagent to a fixed concentration of RNA followed by tRNA binding. Conditions were chosen that approximately half of the total RNA retained its ability to assemble into a functional $30 \mathrm{~S}$ subunit. Accordingly, for assessing early stage of $30 \mathrm{~S}$ subunit assembly, 200 pmol of $E$. coli $16 \mathrm{~S}$ rRNA in RecA buffer $\left(80 \mathrm{mM} \mathrm{K}{ }^{+}\right.$-HEPES at pH 7.6, $20 \mathrm{mM} \mathrm{MgCl}_{2}, 330$ $\mathrm{mM} \mathrm{KCl}$ and $0.01 \%$ Nikkol) purified as described (Culver and Noller 1999) was incubated with $2.9 \mu \mathrm{L}$ of $3.5 \mathrm{M} \mathrm{DMS}$ (made by diluting $4 \mu \mathrm{L}$ of $10.6 \mathrm{M}$ stock into $8 \mu \mathrm{L} 95 \%$ ethanol) per $200 \mu \mathrm{L}$ reaction or $3.2 \mu \mathrm{L}$ of $10 \%$ kethoxal per $200 \mu \mathrm{L}$ reaction. Modification reactions were carried out on ice for $5 \mathrm{~min}$, which were subsequently quenched by addition of $10 \mu \mathrm{L}$ of $14.4 \mathrm{M}$ 2-mercaptoethanol for DMS reactions or $10 \mu \mathrm{L}$ of $500 \mathrm{mM}$ potassium borate for kethoxal reactions. Modification reagents were further removed by gel filtration through a 2-mL Sephadex G-25 column equilibrated in RecA buffer. 30 S particles were reconstituted as described (Culver and Noller 2000) with modified $16 \mathrm{~S}$ rRNA and TP30 (prepared as in Traub and Nomura 1968 and Holmes and Culver 2004). To separate the functional $30 \mathrm{~S}$ particles from the misassembled particles, a tRNA binding assay was carried as described (von Ahsen and Noller 1995). Before the tRNA binding assay, a buffer exchange by gel filtration with 
Sephadex G-25 column equilibrated in TBB buffer (50 mM HEPES at $\mathrm{pH} 7.6,10 \mathrm{mM} \mathrm{MgCl}_{2}, 100 \mathrm{mM} \mathrm{KCl}$ ) was performed. An aliquot of modified reconstituted subunits before tRNA binding assay was kept on ice as a total modified control for primer extension.

To assess References 36 and 15 late stage of 30 S subunit assembly, 200 pmol 16S rRNA was incubated with 400 pmol TP30 in a standard reconstitution assay (Culver and Noller 1999) at $0^{\circ} \mathrm{C}$ to form RI, which was subsequently subjected to $6.5 \mu \mathrm{L}$ of 880 mM DMS (made by diluting $10 \mu \mathrm{L}$ of $10.6 \mathrm{M}$ stock into $110 \mu \mathrm{L}$ $95 \%$ ethanol) per $400 \mu \mathrm{L}$ reaction or $16 \mu \mathrm{L}$ of $0.4 \%$ kethoxal per $400 \mu \mathrm{L}$ reaction. Excess DMS or kethoxal was quenched and removed as described above. Modified particles were incubated for $15 \mathrm{~min}$ at $42^{\circ} \mathrm{C}$ followed by gel filtration with Sephadex G-25 column equilibrated in TBB buffer. Separation of functional fraction and nonfunctional particles was completed as described (von Ahsen and Noller 1995).

Modified residues in $16 \mathrm{~S}$ rRNA were identified by primer extension analysis as described (Moazed et al. 1986; Xu and Culver 2009). The concentration of rRNA extracted from the unmodified, total modified, unselected, and selected pool was normalized to $0.8 \mathrm{pmol} / \mu \mathrm{L}$.

\section{In vivo analysis of selected residues by specialized ribosome system}

Individual $16 \mathrm{~S}$ rRNA mutations were generated by site-directed mutagenesis using the Stratagene Quick-change kit in the plasmid pKF207. This plasmid contains a single copy of 16S rRNA gene with an altered anti-Shine-Dalgarno sequence (5'-GGGGU-3') under an arabinose inducible promoter (Abdi and Fredrick 2005). Plasmids carrying individual mutations were transformed into KLF10 competent cells that carry a chromosomally encoded lacZ reporter gene with an altered Shine-Dalgarno sequence $\left(5^{\prime}\right.$-AU CCC- $\left.3^{\prime}\right)$. A volume of $50 \mu \mathrm{L}$ of saturated overnight cells grown at $37^{\circ} \mathrm{C}$ with $100 \mu \mathrm{g} / \mathrm{mL}$ Amp was used to inoculate $5 \mathrm{~mL}$ of LB with $100 \mu \mathrm{g} / \mathrm{mL}$ Amp and $1 \mathrm{mM}$ arabinose. Growth at $37^{\circ} \mathrm{C}$ was continued until $\mathrm{OD}_{600}$ of $\sim 0.5$. The $\beta$-galactosidase activity was determined as described (Lancaster and Noller 2005).

\section{Polysome profile analysis of individual $16 \mathrm{~S}$ rRNA mutations}

pLK35 plasmids containing individual 16S rRNA mutations introduced by site-directed mutagenesis were transformed into the POP2136 strain (Yassin et al. 2005), which encodes a temperature-sensitive $\lambda$ repressor gene. The $\operatorname{rrnB}$ operon carried by the pLK35 plasmid is under control of a $\lambda$ promoter that can be regulated by temperature (Douthwaite et al. 1989). POP2136 strains containing mutant rRNA were grown at $30^{\circ} \mathrm{C}$ with $100 \mu \mathrm{g} / \mathrm{mL}$ Amp overnight. Fifty milliliters of fresh LB (containing $100 \mu \mathrm{g} / \mathrm{ml}$ Amp) was inoculated with $100 \mu$ l of the above overnight culture at $42^{\circ} \mathrm{C}$ until $\mathrm{OD}_{600}$ of $\sim 0.5$ to allow expression of mutant $16 \mathrm{~S}$ rRNA. Polysomes were isolated and analyzed as described (Connolly et al. 2008). The ratio of free 30 S subunits to total $30 \mathrm{~S}$ subunits was calculated as described (Connolly et al. 2008). The $16 \mathrm{~S}$ rRNA extracted from the $30 \mathrm{~S}$ and $70 \mathrm{~S}$ ribosomal fractions was analyzed by primer extension using a Cye5-GCGGTATTAGCTA CCGT sequence primer. The band intensity of mature $16 \mathrm{~S}$ rRNA and $17 \mathrm{~S}$ rRNA was quantified using the BioRad VersaDoc and Image J software. The percentage of precursor $16 \mathrm{~S}$ rRNA to $16 \mathrm{~S}$
rRNA was determined as a ratio of band intensity of $17 \mathrm{~S}$ rRNA to the sum of band intensity of 17S rRNA and mature 16S rRNA.

Quantification of plasmid 16S rRNA, distinguished by a C-to-U mutation at 1192, was performed as described (Powers and Noller 1991).

\section{ACKNOWLEDGMENTS}

Z.X. and G.M.C designed and interpreted the experiments and wrote the manuscript. Z.X. performed the experiments. We thank H.F. Noller (University of Santa Cruz) for providing pKF207 plasmid and KLF10 strain; K. Fredrick (Ohio State University) for providing POP2136 strain; and all the Culver laboratory members for comments on the manuscript. This work was supported by NIH funding (GM06432 to G.M.C.).

Received April 28, 2010; accepted July 14, 2010.

\section{REFERENCES}

Abdi NM, Fredrick K. 2005. Contribution of 16 S rRNA nucleotides forming the $30 \mathrm{~S}$ subunit A and P sites to translation in Escherichia coli. RNA 11: 1624-1632.

Adilakshmi T, Ramaswamy P, Woodson SA. 2005. Protein-independent folding pathway of the $16 \mathrm{~S}$ rRNA 5' domain. J Mol Biol 351: 508-519.

Adilakshmi T, Bellur DL, Woodson SA. 2008. Concurrent nucleation of $16 \mathrm{~S}$ folding and induced fit in $30 \mathrm{~S}$ ribosome assembly. Nature 455: $1268-1272$.

Allers J, Shamoo Y. 2001. Structure-based analysis of protein-RNA interactions using the program ENTANGLE. J Mol Biol 311: 75-86.

Brink MF, Verbeet MP, de Boer HA. 1993. Formation of the central pseudoknot in 16S rRNA is essential for initiation of translation. EMBO J 12: 3987-3996.

Cannone JJ, Subramanian S, Schnare MN, Collett JR, D'Souza LM, Du Y, Feng B, Lin N, Madabusi LV, Muller KM, et al. 2002. The comparative RNA web (CRW) site: An online database of comparative sequence and structure information for ribosomal, intron, and other RNAs. BMC Bioinformatics 3: 2. doi: 10.1186/ 1471-2105-3-2.

Connolly K, Rife JP, Culver G. 2008. Mechanistic insight into the ribosome biogenesis functions of the ancient protein KsgA. Mol Microbiol 70: 1062-1075.

Culver GM. 2003. Assembly of the 30 S ribosomal subunit. Biopolymers 68: 234-249.

Culver GM, Noller HF. 1999. Efficient reconstitution of functional Escherichia coli $30 \mathrm{~S}$ ribosomal subunits from a complete set of recombinant small subunit ribosomal proteins. RNA 5: 832-843.

Culver GM, Noller HF. 2000. In vitro reconstitution of 30 S ribosomal subunits using complete set of recombinant proteins. Methods Enzymol 318: 446-460.

Douthwaite S, Powers T, Lee JY, Noller HF. 1989. Defining the structural requirements for a helix in $23 \mathrm{~S}$ ribosomal RNA that confers erythromycin resistance. J Mol Biol 209: 655-665.

Grondek JF, Culver GM. 2004. Assembly of the 30S ribosomal subunit: Positioning ribosomal protein S13 in the S7 assembly branch. RNA 10: 1861-1866.

Guthrie C, Nashimoto H, Nomura M. 1969. Studies on the assembly of ribosomes in vivo. Cold Spring Harb Symp Quant Biol 34: 69-75.

Held WA, Nomura M. 1973. Rate determining step in the reconstitution of Escherichia coli 30 S ribosomal subunits. Biochemistry 12: 3273-3281.

Holmes KL, Culver GM. 2004. Mapping structural differences between 30 S ribosomal subunit assembly intermediates. Nat Struct Mol Biol 11: 179-186. 
Holmes KL, Culver GM. 2005. Analysis of conformational changes in $16 \mathrm{~S}$ rRNA during the course of $30 \mathrm{~S}$ subunit assembly. J Mol Biol 354: 340-357.

Lancaster L, Noller HF. 2005. Involvement of $16 \mathrm{~S}$ rRNA nucleotides G1338 and A1339 in discrimination of initiator tRNA. Mol Cell 20: 623-632.

Lee K, Varma S, SantaLucia J Jr, Cunningham PR. 1997. In vivo determination of RNA structure-function relationships: Analysis of the 790 loop in ribosomal RNA. J Mol Biol 269: 732-743.

Lindahl L. 1975. Intermediates and time kinetics of the in vivo assembly of Escherichia coli ribosomes. J Mol Biol 92: 15-37.

Mizushima S, Nomura M. 1970. Assembly mapping of 30S ribosomal proteins from E. coli. Nature 226: 1214-1218.

Moazed D, Noller HF. 1986. Transfer RNA shields specific nucleotides in $16 \mathrm{~S}$ ribosomal RNA from attack by chemical probes. Cell 47: 985-994.

Moazed D, Noller HF. 1990. Binding of tRNA to the ribosomal A and $\mathrm{P}$ sites protects two distinct sets of nucleotides in $16 \mathrm{~S}$ rRNA. J Mol Biol 211: 135-145.

Moazed D, Stern S, Noller HF. 1986. Rapid chemical probing of conformation in $16 \mathrm{~S}$ ribosomal RNA and $30 \mathrm{~S}$ ribosomal subunits using primer extension. J Mol Biol 187: 399-416.

Nomura M, Traub P. 1968. Structure and function of Escherichia coli ribosomes. 3. Stoichiometry and rate of the reconstitution of ribosomes from subribosomal particles and split proteins. J Mol Biol 34: 609-619.

Powers T, Noller HF. 1991. A functional pseudoknot in 16S ribosomal RNA. EMBO J 10: 2203-2214.

Powers T, Stern S, Changchien LM, Noller HF. 1988. Probing the assembly of the $3^{\prime}$ major domain of $16 \mathrm{~S}$ rRNA. Interactions involving ribosomal proteins S2, S3, S10, S13 and S14. J Mol Biol 201: $697-716$.

Powers T, Daubresse G, Noller HF. 1993. Dynamics of in vitro assembly of $16 \mathrm{~S}$ rRNA into $30 \mathrm{~S}$ ribosomal subunits. J Mol Biol 232: 362-374.

Pulk A, Maivali U, Remme J. 2006. Identification of nucleotides in E. coli $16 \mathrm{~S}$ rRNA essential for ribosome subunit association. RNA 12: $790-796$.
Ramaswamy P, Woodson SA. 2009. S16 throws a conformational switch during assembly of $30 \mathrm{~S} 5^{\prime}$ domain. Nat Struct Mol Biol 16: $438-445$.

Schlessinger D. 1974. Ribosome formation in Escherichia coli. Cold Spring Harbor, NY.

Schuwirth BS, Borovinskaya MA, Hau CW, Zhang W, Vila-Sanjurjo A, Holton JM, Cate JH. 2005. Structures of the bacterial ribosome at $3.5 \AA$ resolution. Science 310: $827-834$.

Stern S, Weiser B, Noller HF. 1988. Model for the three-dimensional folding of 16 S ribosomal RNA. J Mol Biol 204: 447-481.

Stern S, Powers T, Changchien LM, Noller HF. 1989. RNA-protein interactions in $30 \mathrm{~S}$ ribosomal subunits: Folding and function of 16S rRNA. Science 244: 783-790.

Sykes MT, Williamson JR. 2009. A complex assembly landscape for the 30 S ribosomal subunit. Annu Rev Biophys 38: 197-215.

Talkington MW, Siuzdak G, Williamson JR. 2005. An assembly landscape for the 30S ribosomal subunit. Nature 438: 628-632.

Traub P, Nomura M. 1968. Structure and function of E. coli ribosomes. V. Reconstitution of functionally active 30S ribosomal particles from RNA and proteins. Proc Natl Acad Sci 59: $777-784$.

Traub P, Nomura M. 1969. Structure and function of Escherichia coli ribosomes. VI. Mechanism of assembly of $30 \mathrm{~S}$ ribosomes studied in vitro. J Mol Biol 40: 391-413.

von Ahsen U, Noller HF. 1995. Identification of bases in 16S rRNA essential for tRNA binding at the $30 \mathrm{~S}$ ribosomal P site. Science 267: 234-237.

Warner JR, Vilardell J, Sohn JH. 2001. Economics of ribosome biosynthesis. Cold Spring Harb Symp Quant Biol 66: 567-574.

Wimberly BT, Brodersen DE, Clemons WM Jr, Morgan-Warren RJ, Carter AP, Vonrhein C, Hartsch T, Ramakrishnan V. 2000. Structure of the 30S ribosomal subunit. Nature 407: 327-339.

$\mathrm{Xu}$ ZL, Culver GM. 2009. Chemical probing of RNA and RNA/protein complexes. Meth Enzymol 468: 147-165.

Yassin A, Fredrick K, Mankin AS. 2005. Deleterious mutations in small subunit ribosomal RNA identify functional sites and potential targets for antibiotics. Proc Natl Acad Sci 102: 1662016625. 

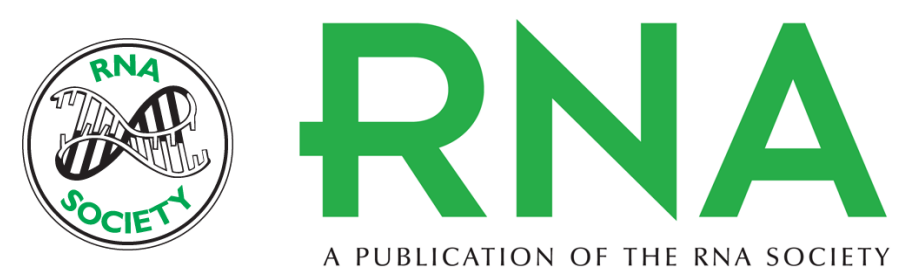

A PUBLICATION OF THE RNA SOCIETY

\section{Differential assembly of $16 \mathrm{~S}$ rRNA domains during $30 \mathrm{~S}$ subunit formation}

Zhili Xu and Gloria M. Culver

RNA 2010 16: 1990-2001 originally published online August 24, 2010

Access the most recent version at doi:10.1261/rna.2246710

\section{References This article cites 41 articles, 11 of which can be accessed free at: http://rnajournal.cshlp.org/content/16/10/1990.full.html\#ref-list-1}

\section{License}
Email Alerting Receive free email alerts when new articles cite this article - sign up in the box at the Service top right corner of the article or click here.

